\title{
PENINGKATAN AKTIVITAS DAN HASIL BELAJAR PESERTA DIDIK MELALUI MODEL DISCOVERY LEARNING DENGAN VARIASI MODEL CAROUSELL FEEDBACK PADA PEMBELAJARAN PPKn
}

\author{
Asep Sutisna Putra \\ SMP Negeri 17 Tasikmalaya \\ e-mail : spsutisna@yahoo.com
}

\begin{abstract}
This study aims to determine the effectiveness of PPKn learning by using the Discovery Learning model with variations of Carousell Feedback in improving student activity and learning outcomes in the Unity in Diversity of Indonesian Nation material in Class IX - B of SMP Negeri 17 Tasikmalaya in the 2018/2019 academic year. This research is a classroom action research model of Kemmis and Taggart, conducted in two cycles with each conducted in $\mathbf{2}$ meetings. The stages of each cycle consist of planning, implementing actions, observing and reflecting. Data was collected through learning outcomes tests, observations of student activities. The results of the analysis of the data obtained that the activities of students in pre-action by 25 $\% \%$ to $100 \%$ in the second cycle, means an increase in student learning activities by $75 \%$. The mean of learning outcomes increased from $\mathbf{7 2 . 3 8}$ in the first cycle to $\mathbf{8 4 . 3 8}$ in the second cycle. The percentage of mastery learning increased from $15.63 \%$ in pre-action to $96.88 \%$ in the second cycle, meaning an increase of $81.25 \%$. From these data it can be concluded that learning by using discovery learning models with variations of the carousell feedback model is effective in increasing students' learning activities and outcomes on Unity diversity in SARA diversity within the Unity in Diversity frame of students in class IX - B of Junior High School 17 Tasikmalaya .
\end{abstract}

Kata kunci : Learning Outcomes, Discovery Learning, Crousell Feedback.

Abstrak

Penelitian ini bertujuan untuk mengetahui efektifitas pembelajaran PPKn dengan menggunakan model Discovery Learning dengan variasi Carousell Feedback dalam meningkatkan aktivitas dan hasil belajar peserta didik pada materi Persatuan dalam Keberagaman Bangsa Indonesia di Kelas IX - B SMP Negeri 17 Tasikmalaya tahun pelajaran 2018/2019. Penelitian ini merupakan penelitian tindakan kelas dengan model Kemmis and Taggart, dilaksanakan dalam dua siklus dengan masing-masing dilaksanakan dalam 2 pertemuan. Tahapan tiap siklus terdiri dari perencanaan, pelaksanaan tindakan, observasi dan refleksi. Data dikumpulkan melalui tes hasil belajar, observasi aktivitas peserta didik. Hasil analisis terhadap data yang diperoleh bahwa aktivitas peserta didik pada pra tindakan sebesar $25 \% \%$ menjadi $100 \%$ pada siklus II, berarti terjadi peningkatan aktivitas belajar peserta didik sebesar $75 \%$. Rerata hasil belajar meningkat dari 72,38 di siklus I menjadi 84,38 pada siklus II. Presentasi ketuntasan belajar meningkat dari 15,63\% pada pra tindakan menjadi $96,88 \%$ pada siklus II, berarti terjadi peningkatan sebesar $81,25 \%$. Dari data-data tersebut dapat disimpulkan bahwa pembelajaran dengan menggunakan model discovery learning dengan variasi model carousell feedback efektif dalam meningkatkan aktivitas dan hasil belajar peserta didik pada materi Persatuan dalam keragaman SARA dalam bingkai Bhinneka Tunggal Ika pada peserta didik kelas IX - B SMP Negeri 17 Tasikmalaya.

Kata kunci : Hasil Belajar, Discovery Learning, Crousell Feedback. 
p-ISSN : 2655-7304

e-ISSN : 2655-8963

\section{PENDAHULUAN}

Pembelajaran PPKn pada Kurikulum 2013 menggunakan pendekatan saintifik atau pendekatan berbasis proses keilmuan, dengan strategi pembelajaran kontekstual. Pendekatan saintifik dapat menggunakan beberapa model pembelajaran yang merupakan suatu bentuk pembelajaran yang memiliki nama, ciri, sintaks, pengaturan, dan budaya. Model pembelajaran yang dikembangkan dalam PPKn yaitu discovery learning, inquiry learning, problem-based learning, dan project-based learning, disamping model-model pembelajaran khas PPKn. Penerapan model pembelajaran yang sesuai diharapkan peserta didik aktif berfikir secara kritis terhadap persoalan-persoalan yang dihadapi dengan mengkaji berbagai literatur, mengamati lingkungan, dan berdiskusi secara intensif untuk menemukan langkah-langkah yang tepat dalam menyelesaikan masalah tersebut melalui langkah-langkah pembelajaran yang telah direncanakan.

Proses pembelajaran seperti itulah yang seharusnya dilaksanakan di kelas. Di SMP Negeri 17 Tasikmalaya, pembelajaran PPKn sebenarnya dalam perencanaan sudah menggunakan pendekatan saintifik, namun dalam pelaksanaannya prosedur pembelajaran saintifik belum sepenuhnya diaksanakan. Model pembelajaran saintifik juga belum terlaksana dengan baik, sesuai langkah-langkah model-model tersebut. Hal ini berimplikasi terhadap kondisi kelas yang cenderung pasif, sulit untuk terjadinya interaksi yang aktif antar peserta didik maupun dengan guru. Peserta didik hampir tidak berani untuk bertanya apalagi untuk menjawab pertanyaan dan mengemukakan pendapat. Disamping itu, bila bekerja kelompok sebagian besar peserta didik hanya mengandalkan satu atau dua orang saja yang mengerjakan tugas-tugas dalam kelompok.

Kecenderungan seperti itu terlihat dari hasil pembelajaran pada kompetensi dasar sebelumnya, yaitu pada Kompetensi Dasar Kedaulatan Negara Republik Indonesia yang menunjukkan bahwa peran serta peserta didik pada pembelajaran PPKn hanya berkisar pada $25 \%$ (8 orang) yang aktif dalam pembelajaran, sementara hasil belajar sebelum dilakukan perbaikan berupa remidial menunjukkan rata-rata 72,38 dengan KKM 75, dimana 15,63\% (5 orang) telah mencapai KKM.

Dari permasalahan tersebut di atas, maka diperlukan forrmula yang tepat dalam membelajarkan peserta didik, sehingga hasilnya sesuai yang diharapkan. Untuk itu, disodorkan upaya berupa pembelajaran dengan pendekatan saintifik menggunakan model pembelajaran Discovery Learning yang divariasikan dengan model carousell feedback dipandang sangat ideal diterapkan pada mata pelajaran PPKn, hal ini sejalan dengan tujuan PPKn diantaranya melatih peserta didik untuk berfikir kritis, rasional, dan kreatif serta memiliki semangat kebangsaan dengan melibatkan seluruh potensi peserta didik.

Berdasarkan pemikiran di atas, yang menjadi permasalahan pada penelitian ini adalah kurangnya partisipasi peserta didik dalam pembelajaran dan hasil belajar yang masih rendah. Dari permasalahan di atas maka, rumusan masalah pada penelitian ini adalah apakah pembelajaran PPKn dengan menggunakan model discovery learning dengan variasi model carousell feedback dapat meningkatkan hasil belajar peserta didik di kelas IX-B SMP Negeri 17 Kota Tasikmalaya Tahun Pelajaran tahun pelajaran 2018 - 2019? dan apakah model discovery learning dengan variasi model carousell feedback efektif dalam meningkatkan hasil belajar peserta didik? Secara umum tujuan penelitian ini adalah untuk mengetahui efektivitas model pembelajaran discovery learning dan model carousell feedback dalam meningkatkan hasil belajar peserta didik di kelas IX-B SMP Negeri 17 Kota Tasikmalaya Tahun Pelajaran tahun pelajaran $2018-2019$. 
p-ISSN : 2655-7304

e-ISSN : 2655-8963

\section{KAJIAN PUSTAKA}

\section{Pembelajaran Discovery dengan Variasi Caroussel Feddback}

Discovery learning didefinisikan sebagai proses pembelajaran yang terjadi, bila materi pembelajaran tidak disajikan dalam bentuk final, tetapi peserta didik mengorganisasikan sendiri pengetahuannya (Kurniasih, Sani : 2014). Disamping itu Hosnan (2014 : 282) mengemukakan bahwa discovery learning adalah suatu model pembelajaran yang mengembangkan cara berfikir aktif dengan menemukan sendiri, menyelidiki sendiri, sehingga hasilnya akan bertahan lama dalam ingatan.

Jadi model pembelajaran ini menekankan agar peserta didik mampu menemukan informasi dan memahami konsep pembelajran secara mandiri berdasarkan kemampuan yang dimilikinya. Guru berperan sebagai fasilitator yang mendorong peserta didik untuk berfikir sendiri, menganalisis sendiri, dan menyimpulkannya, sehingga peserta didik dapat menemukan prinsip-prinsip umum (generalisasi) berdasarkan bahan atau data yang telah didapatnya.

Pelaksanaan model discovery learning di dalam kelas menurut Syah (2004) dalam Kemdikbud (2018 : 18 - 19) mengemukakan bahwa implementasi model discovery learning tahapannya sebagai berikut :

1. Tahap stimulasi / pemberian rangsangan (stimulation)

Pada tahapan ini guru memulai pembelajaran dengan mengajukan pertanyaan, melempar kasus, memutar video, anjuran membaca buku, dan aktivitas belajar lainnya yang mengarah pada persiapan pemecahan masalah. Stimulus ini berfungsi untuk menyediakan kondisi interaksi belajar yang dapat mengembangkan dan membantu peserta didik dalam mengeksplorasi bahan.

2. Tahap pernyataan / identifikasi masalah (problem statement)

Pada tahap ini guru memberi kesempatan kepada peserta didik untuk mengidentifikasi sebanyak mungkin masalah yang relevan dengan bahan pelajaran, kemudian salah satunya dipilih dan dirumuskan dalam bentuk hipotesis.

3. Tahap pengumpulan data (data collection)

Tahap ini peserta didik melakukan eksplorasi, guru memberikan kesempatan kepada peserta didik untuk mengumpulkan informasi sebanyak-banyaknya yang relevan untuk memecahkan masalah atau membuktikan hipotesis. Data dapat diperoleh dengan membaca buku, mengamati objek, wawancara, browsing internet atau melakukan uji coba.

4. Tahap pengolahan data (data processing)

Tahap ini peserta didik melakukan analisis atas data dan informasi yang dikumpulkan, kemudian ditafsirkan sesuai rumusan masalah.

5. Tahap pembuktian (verifikcation)

Pad tahap ini peserta didik secara cermat membuktikan benar atau tidaknya hipotesis yang telah ditetapkan dihubugkan dengan hasil pengoahan data.

6. Tahap menarik kesimpulan / generalisasi (generalization)

Peserta didik menarik kesimpulan terhadap masalah atau hipotesis dengan memperhatikan hasil verifikasi. Kemudian peserta didik menarik kesimpulan.

Tahapan-tahapan tersebut harus senantiasa terlaksana dalam pembelajaran. Jika tahapan tersebut dilaksanakan tentu kelebihan dari model Discovery Learning akan membawa dampak yang baik dalam proses pembelajaran. Untuk itu Hosnan (2014 : 287 - 288) mengemukakan kelebihan dari model ini, yaitu : 
p-ISSN : 2655-7304

e-ISSN : 2655-8963

1. Peserta didik dibantu untuk memperbaiki dan meningkatkan ketrampilan dan proses kognitif

2. Pengetahuan yang diperoleh sangat pribadi dan ampuh, karena menguatkan pengertian, ingatan dan transfer

3. Meningkatkan kemampuan peserta didik dalam memecahkan masalah

4. Membantu peserta didik memperkuat konsep diri

5. Mendorong aktivitas peserta didik

6. Mendorong peserta didik untuk merumuskan hipotesis sendiri

7. Melatih peserta didik untuk belajar mandiri

8. Peserta didik lebih aktif dalam pembelajaran

Model pembelajaran ini merupakan salah satu dari model pembelajaran cooperative yang dikembangkan oleh Kagan dan Kagan (2009). Model pembelajaran ini merujuk pada rotasi kelompok seperti halnya komedi putar, sedangkan feedback merujuk pada pemberian tanggapan dari kelompok lain terhadap kelompok yang datang. Kagan mengartikan bahwa carousell feedback adalah interaksi peserta didik secara bersamaan untuk berbagi ide dalam sebuah projek, dimana memunngkinkan berbagi ide, solusi atau projek secara efisien. Dengan kata lain dalam pembelajaran model carousell feedback peserta didik berinteraksi secara intensif untuk saling memberikan ide, solusi secara efisieun yang memungkikan peserta didik berbagi dalam mengidentifikasi masalah, berbagi sumber dan pengalaman dan berbagi ide-ide dalam upaya menyelesaikan masalah, jadi peserta didik pada pembelajaran dengan model carousell feedback dapat berperan serta secara aktif, bersikap kritis dan responsip terhadap permasalahan-permasalahan yang dibahas dalam pembelajaran.

Langkah-langkah model pembelajaran carousell feedback :

1. Peserta didik dikelompokan dalam kelompok dengan anggota 4 - 5 orang

2. Tiap kelompok membahas satu topik atau masalah yang telah disepakati

3. Kelompok membahas topiknya masing-masing

4. Anggota kelompok dibagi 2, sebagian tinggal di kelompok sebagian lagi pindah ke kelompok lain

5. Guru memberikan aba-aba waktu tiap perpindahan kelompok.

6. Anggota kelompok yang tinggal di kelompok menjelaskan bahsan topiknya ke kelompok yang datang, kemudian kelompok yang datang menuliskan pendapatanya terhadap permasalahan kelompok yang di datangi dengan menuliskannya di karton yang telah disediakan dengan warna spidol yang berbeda tiap kelompok

7. Setelah kembali ke kelompok awal, anggota kelompok yang tinggal menjelaskan kegiatan yang dilakukan dan menyampaikan masukan-masukan, pendapat-pendapat atau sanggahan-sanggahan dari kelompok lain terhadap topik yang dibahas.

8. Mendiskusikan topik yang dibahas dengan memberhatikan masukan-masukan (feedback) dari kelompok lain.

9. Presentasi hasil kelompok.

\section{METODOLOGI PENELITIAN}

Penelitian ini akan dilaksanakan dengan menggunakan metode Penelitian Tindakan Kelas (classroom action research) yang berusaha mengkaji dan merefleksi secara kolaboratif suatu alternatif pembelajaran sebagai bentuk penelitian yang bersifat reflektif dengan melakukan tindakan-tindakan tertentu agar dapat memperbaiki dan atau meningkatkan praktek-praktek pembelajaran di kelas. 
Adapun populasi pada Penelitian Tindakan Kelas ini adaah peserta didik kelas IX-B SMP Negeri 17 Kota Tasikmalaya semester 2 Tahun Pelajaran tahun pelajaran 2018-2019 berjumlah 32 orang, terdiri dari 12 orang laki-laki dan 20 orang perempuan. Dalam pelaksanaannya, penelitian ini dibantu oleh satu orang observer untuk mengamati aktivitas guru dan siswa serta interaksi antara guru dan peserta didik. Penelitian Tindakan Kelas ini menggunakan model yang mengacu pada Model Penelitian Tindakan Kelas yang dikemukakan oleh Kemmis dan Taggart (Hopkins, 2014 : 61)

Penelitian Tindakan Kelas merupakan sebuah siklus dengan tahapan Perencanaan, Tindakan, Observasi dan Refleksi. Hasil refleksi kemudian digunakan untuk membuat perencanaan dan tindakan pada siklus berikutnya, sehingga pembelajaran pada siklus berikutnya diharapkan akan lebih baik dari siklus sebelumnya. Pada penelitian ini menggunakan 2 (dua) siklus. Masing-masing siklus dilaksanakan dalam satu kali pertemuan.

Tahapan Penelitian dilaksanakan dengan tahapan sebagai berikut :

a. Perencanaan

Pada tahap ini peneliti mulai melakukan identifikasi masalah dan penetapan alternatif pemecahan masalah, penyusunan rencana pembelajaran, format pengamatan, penilaian dan rencana tindakan yang berkolaborasi dengan rekan guru mata pelajaran PPKn yang lain yaitu Deti Hermayanti, S.Pd.

b. Tindakan

Tahap ini merupakan tahap pelaksanaan tindakan yang telah direncanakan sebelumnya, dimana penelitian ini dilaksanakan dalam 2 siklus, masing-masing siklus dilaksanakan dalam 2 kali pertemuan. Siklus pertama dilaksanakan pada tanggal 9 dan 16 Januari 2019, sedangkan siklus kedua dilaksanakan pada tanggal 23 dan 30 Januari 2019.

c. Observasi

Pengamatan dilakukan oleh observer (guru pengamat) dengan mengacu pada format observasi yang telah dibuat pada saat perencanaan tindakan untuk mengamati serangkaian kegiatan pembelajaran baik aktifitas siswa, aktifitas guru dan interaksi antara guru dan siswa. Dimana format observasi ini digunakan untuk menilai dan mengamati hasil belajar, aktivitas peserta didik, dan presentasi kelompok.

d. Refleksi

Refleksi merupakan diskusi terhadap temuan-temuan yang diperoleh dalam pelaksanaan tindakan yang berkaitan dengan penampilan guru di kelas, aktivitas siswa, dan hasil belajar siswa mengenai kekurangan-kekurangan maupun kelebihan dari tahap pelaksanaan. Berpedoman dari kekurangan pada siklus 1 maka dibuat perencanaan pada siklus 2. Hasil dari refleksi ini dijadikan sebagai bahan untuk memperbaiki proses pembelajaran pada siklus berikutnya, sehingga proses pembelajaran diharapkan lebih meningkat.

Sementara itu data dikumpulkan melalui lembar observasi, hasil tes, dan dokumentasi.

\section{HASIL PENELITIAN DAN PEMBAHASAN}

Penelitian dilaksanakan pada bulan Januari 2019 dengan 2 siklus, dimana masingmasing siklus dilaksanakan dalam 2 pertemuan.

\section{Siklus pertama}

Siklus pertama dilaksanakan pada tanggal 9 dan 16 januari 2019. Pada pertemuan pertama diawali dengan pembentukan kelompok, masing-masing kelompok beranggotakan 4 orang peserta didik, dilanjutkan dengan mengamati video tentang puisi tanah airku, peserta 
didik diminta untuk mengidentifikasi masalah-masalah yang terjadi berkaitan dengan puisi yang telah disimak, kemudian memilih satu masalah yang akan dipecahkan, peserta didik mencari / mengumpulkan data yang berkaitan dengan masalah yang telah dikemukakan tadi dengan browsing internet, hasil yang diperoleh dari hasil browsing internet kemudian diidentifikasi kembali dan diolah untuk mencari kesimpulan sementara, kemudian browsing kembali untuk memastikan kebenaran dari kesimpulan tersebut. Pada pertemuan kesatu peserta didik baru menyelesaikan tugasnya pada fase memverifikasi kesimpulan sementaranya, tahapan berikutnya dilaksanakan pada pertemuan ke-2.

Pada pertemuan kedua ini peserta didik menyiapkan hasil diskusi minggu yang lalu untuk dipresentasikan di depan kelas, kemudian dilanjutkan dengan presentasi tiap kelompok ke depan kelas, diakhiri dengan penguatan dari guru dan tanya jawab berkaitan dengan permasalahan yang dibahas sebagai evalusi.

Pada siklus pertama ini, dilaksanakan pengamatan oleh observer untuk mengamati aktivitas peserta didik dalam pembelajaran, meliputi antusias dalam diskusi, mengajukan pertanyaan/menjawab pertanyaan, aktif browsing internet untuk mengumpulkan data, dan presentasi.

Berdasarkan hasil pengamatan terhadap peserta didik dalam proses pembelajaran pada siklus pertama diperoleh data bahwa peserta didik yang aktif dalam pembelajaran siklus pertama sebanyak 20 orang $(62.5 \%)$ sedangkan sisanya sebanyak 12 orang (37.5\%) tidak aktif seperti terlihat pada grafik di bawah ini :

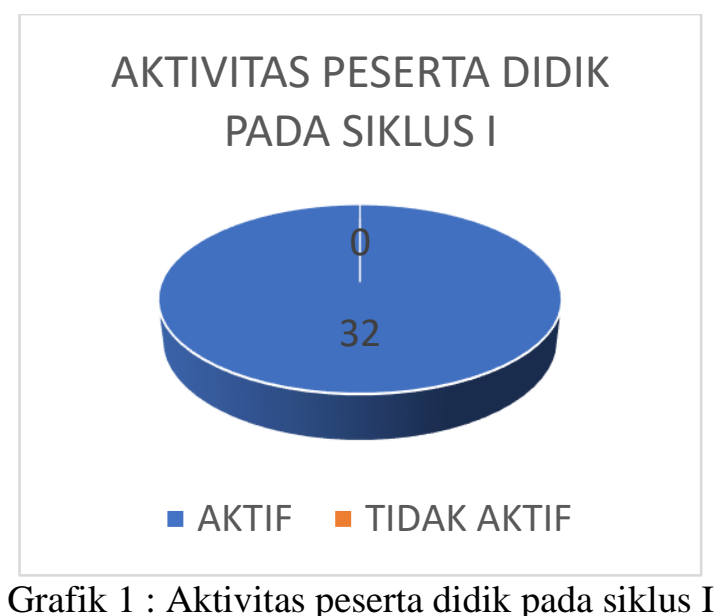

Dikatakan aktif apabila peserta didik berdasakan pengamatan mendapat minimal 3 ceklist dari indicator pengamatan, kalau ceklisnya kurang dai 3 maka dikatakan peserta didik tersebut tidak aktif. Sedangkan hasil belajar berdasarkan tes yang dilaksanakan diperoleh data 19 orang $(59.38 \%)$ telah mencapai KKM, sedangkan sisanya sebanyak 13 orang $(40.62 \%)$ belum mencapai KKM dengan rerata sebesar 75,47.

Setelah siklus pertama selesai dilakukan refleksi berkaitan kelebihan dan kekurangan dalam proses pembelajaran. Diperoleh kesimpulan bahwa perlu aktivitas peserta didik yang lebih agar hasil pembelajaran lebih baik. Setelah berdiskusi disepakati menambah model pembelajaran kooperatif carousell feedback pada siklus kedua, dengan pertimbangan bahwa model ini menuntut peserta didik lebih aktif dalam mengemukakan pendapat karena ada keharusan memberikan masukan / feedback kepada kelompok lain yang didatangi, dan disatu 
sisi peserta didik harus mampu menjelaskan hasil diskusinya kepada teman yang datang pada kelompoknya. Model ini disisipkan pada model Discovery learning pada sintax mengumpulkan data/informasi setelah dilakukan browsing internet dengan diawali penyampaian masalah yang dikaji oleh masing-masing kelompok.

\section{Siklus II}

Berdasarkan perencanaan yang dibuat dengan memperhatikan hasil refleksi siklus I, maka dilaksanakan siklus kedua yang dilaksanakan pada tanggal 23 dan 30 Januari 2019. Peserta didik berkumpul dalam kelompok, kemudian menyimak video berupa lagu tentang ajakan untuk bergotong royong dengan judul Sabilulungan. Kemudian peserta didik diarahkan terhadap pentingnya kerjasama atau gotong royong dalam keberagaman bangsa Indonesia, kemudian peserta didik mengidentifikasi masalah berkaitan dengan keragaman bangsa Indonesia.

Peserta didik mengumpulkan informasi dengan membaca buku paket PPKn kelas IX Bab 4, browsing internet untuk mecari bahan-bahan dalam memecahkan masalah yang dipilih oleh kelompoknya, dilanjutkan dengan mengkaji permasalahan kelompok lain dengan mencari satu bahan masukan untuk kelompok lain. Hasil browsing kemudian diolah dan dituliskan dalam kertas karton.

Setelah data terkumpul peserta didik dalam kelompok dibagi dua, dua orang tinggal di kelompoknya dua orang lagi berkunjung ke kelompok lain untuk mendapat penjelasan tentang masalah yang dikaji dan penyelesaiannya, kemudian memberikan masukan ke kelompok tersebut. Terus berputar sampai kembali ke kelompok masing-masing, tiap putaran diberi waktu 5 menit. Setelah putaran selesai, tiap kelompok mendiskusikan kembali hasil diskusinya dengan memperhatikan masukan dari kelompok lain, kemudian dituliskan kembali dalam kertas karton untuk dipresentasikan di depan kelas.

Dari tindakan siklus II tersebut, diperoleh data pengamatan terhadap aktivitas peserta didik, dimana peserta didik yang aktif dalam pembelajaran sebanyak 32 orang (100\%). Dengan demikian pada siklus II seluruh peserta didik aktif dalam kegiatan pembelajaran.

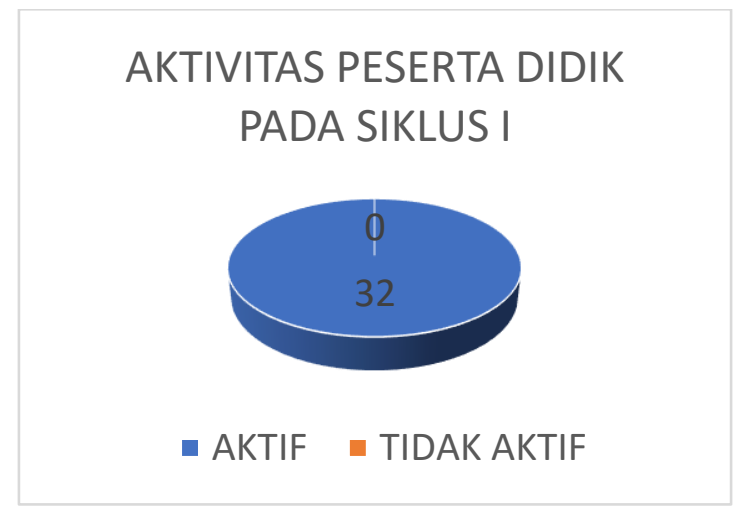

Grafik 2 : Aktivitas peserta didik pada siklus II 
Sedangkan hasil belajar diperoleh data, sebanyak 31 orang $(96,88 \%)$ telah melebihi KKM, sedangkan sisanya sebanyak 1 orang $(3,22 \%)$ belum mencapai KKM, sementara reratanya menunjukkan 84,38 .

\section{PEMBAHASAN HASIL PENELITIAN}

Berdasarkan data-data yang diperoleh pada pelaksanaan tindakan pada siklus I dan II terlihat bahwa aktivitas peserta didik meningkat seiring dengan perbaikan perencanaan pembelajaran dan pelaksanaan pembelajaran, perbandingannya terlihat pada Grafik di bawah ini.

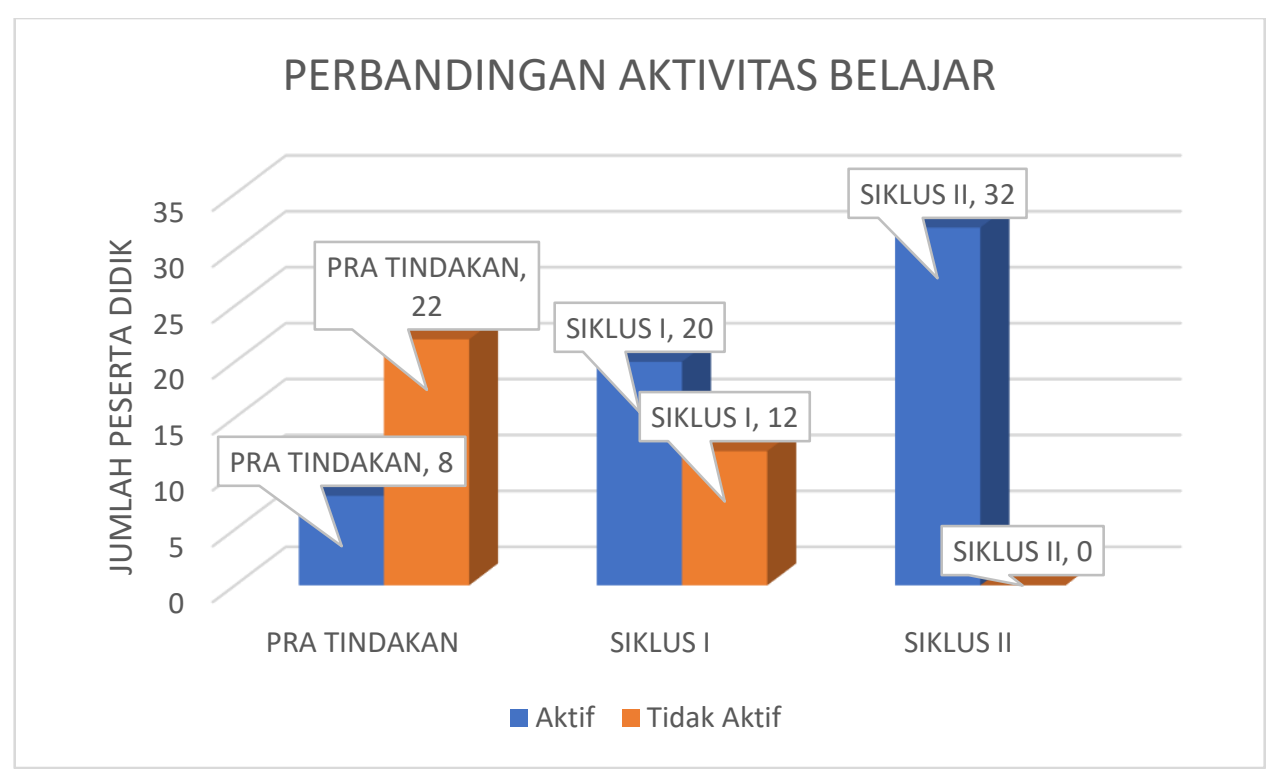

Grafik 3 : Perbandingan aktivitas belajar peserta didik

Berdasarkan tabel tersebut terlihat bahwa terdapat peningkatan aktivitas belajar peserta didik dari pratindakan sebesar 25\%, siklus I sebesar $62.5 \%$ sedangkan siklus II seluruh peserta didik $(100 \%)$ aktif dalam pembelajaran. Dengan demikian terjadi peningkatan yang cukup signifikan setelah dilakukan tindakan, baik pada siklus I maupun II sebesar $75 \%$.

Sedangkan hasil belajarnya berdasarkan data yang diperoleh pada siklus I dan siklus II perbandingannya terlihat pada grafik berikut. 


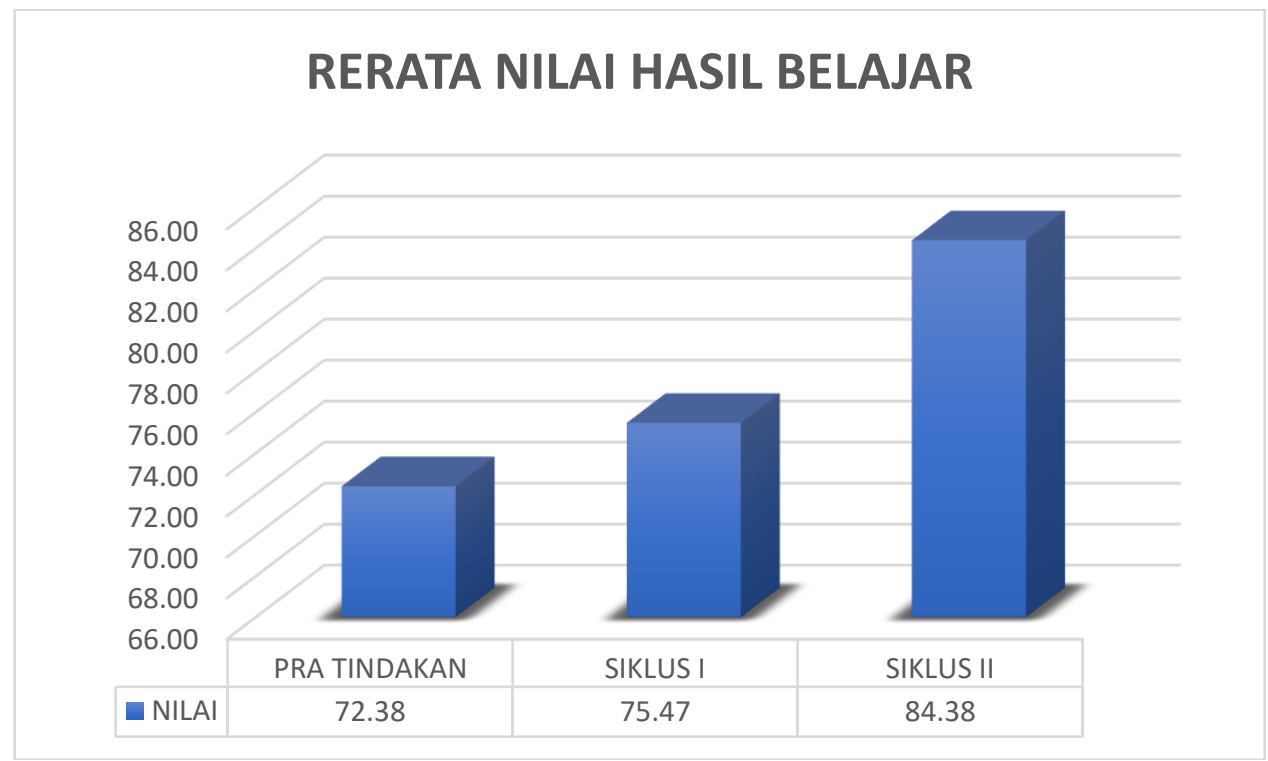

Grafik 4 : Perbandingan rerata nilai peserta didik

Dari grafik tersebut di atas terlihat bahwa nilai yang diperoleh peserta didik terdapat peningkatan, dari pratindakan ke siklus I terdapat peningkatan sebesar 4,27\%, sementara dari siklus I ke siklus II terdapat peningkatan sebesar 11,80\%. Dengan demikian selama dilakukan tindakan pada siklus I da siklus II terdapat peningkatan hasil belajar sebesar $16,07 \%$ dari kondisi awal.

Meskipun peningkatan rerata nilainya tidak terlalu besar, tetapi peningkatan peserta didik yang telah mencapai KKM dari siklus I ke siklus II ternyata cukup besar, seperti terlihat pada grafik di bawah ini.

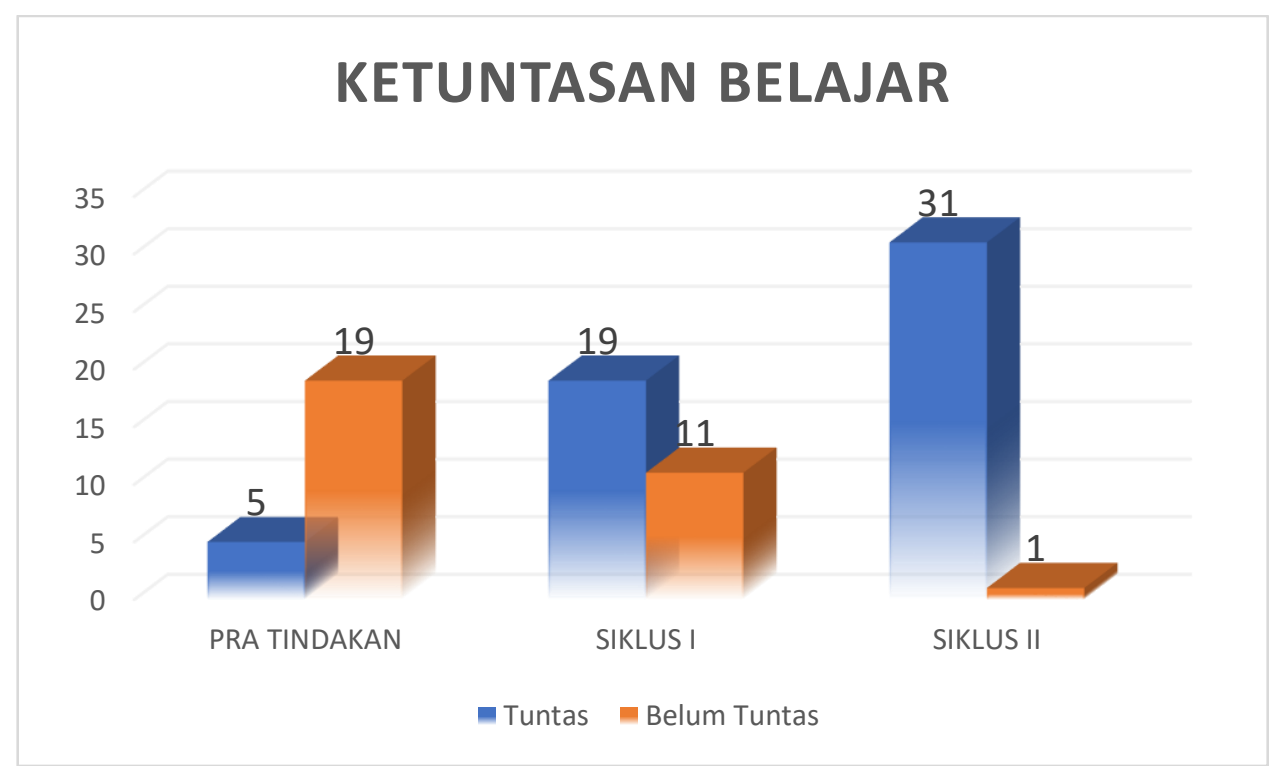

Grafik 5 : Perbandingan ketuntasan belajar peserta didik 
p-ISSN : 2655-7304

e-ISSN : 2655-8963

Dari grafik di atas peningkatan ketuntasan belajar peserta didik peningkatannya cukup berarti, dimana peningkatan dari pratindakan ke siklus I sebesar $43.75 \%$, sementara dari siklus I ke siklus II peningkatannya sebesar 37.5\%. Jadi secara keseluruhan tindakan dari pratindakan ke siklus II sebesar $81,25 \%$.

Berdasarkan hasil-hasil penelitian dan pembahasan di atas menunjukkan bahwa pembelajaran PPKn dengan menggunakan model discovery learning dengan variasi model carousell feedback efektif meningkatkan aktivitas dan hasil belajar peserta didik. Hal ini sejalan dengan pendapat Mulyasa (2002) bahwa suatu proses pembelajaran dikatakan efektif apabila sasaran atau tujuan mampu tercapai. Pada penelitian ini indikator efektivitas peneliti menetapkan indicator efektif adalah 1) kemampuan guru mengelola pembelajaran, 2) peningkatan aktivitas belajar peserta didik, dan 3) meningkatnya hasil belajar peserta didik pasca tindakan.

\section{KESIMPULAN}

Berdasarkan hasil penelitian dan pembahasan dapat disimpulkan bahwa pembelajaran PPKn dengan menggunakan model discovery learning dengan variasi carousell feedback mampu meningkatkan aktivitas dan hasil belajar peserta didik, hal ini terlihat dari meningkatnya aktivitas dan hasil belajar peserta didik dari siklus I ke siklus II secara signifikan.

Dapat disimpulkan pula bahwa pembelajaran PPKn dengan menggunakan model discovery learning dengan variasi carousell feedback ternyata mampu meningkatkan aktivitas dan hasil belajar peserta didik, hal ini dibuktikan dengan tercapainya indicator-indikator efektivitas pembelajaran yang telah ditetapkan.

Pembelajaran dengan menggunakan pendekatan saintifik sebenarnya sudah sangat baik dalam meningkatkan aktivitas dan hasil belajar. Untuk itu penulis mengajak kepada rekanrekan guru untuk lebih kreatif dan inovatif dalam mengembangkan, memodifikasi, atau mengadaptasikan model-model pembelajaran supaya tujuan pembelajaran dapat tercapai dengan baik

\section{DAFTAR PUSTAKA}

[1] Hanifah, Nurdinah. 2014. Memahani Penelitian Tindakan Kelas : Teori dan Aplikasinya. Bandung : UPI Press

[2] Honan, M. 2014. Pendekatan Saintifik dan Kontekstual dalam Pembelajaran Abad 21. Bogor Ghalia Indonesia

[3] Hopkins, David. 2014. A Teachers Guide to Classroom Research, fifth edition. New York : Open University Press

[4] Kagan, S. dan Kagan, M. 2009. Kagan Cooperative Learning. California: Kagan Publishing.

[5] Kurniasih, Sani. 2014. Strategi-strategi Pembelajaran. Bandung : Alfabeta

[6] Tan, Thomas. 2017. Teaching is an Art : Maximize Your Teaching. Yogyakarta : Deepublish

[7] Kemdikbud. 2017. Pendidikan Pancasila dan Kewarganegaraan : Buku Guru. Jakarta : Kemdikbud 
p-ISSN : 2655-7304

e-ISSN : 2655-8963

[8] Mulyasa, E. 2002. Manajemen berbasis sekolah, Konsep, strategi dan implementasi. Bandung : Remaja Rosdakarya 